Session 1106

\title{
Student Competitions and Experience Enhance ABET Requirements
}

\author{
Enno "Ed" Koehn, Rajesh D. Malani \\ Lamar University
}

\begin{abstract}
The Accreditation Board for Engineering and Technology (ABET) has adopted a revised set of criteria for accrediting engineering programs. Nevertheless, as in the past, civil engineering departments will be required to demonstrate proficiency in specific subject areas which are included in the ABET program criteria.

This paper investigates, according to civil engineering students, the level at which their understanding of various subjects required by ABET and listed in the Program Criteria for Civil and Similarly Named Engineering Programs and the General Criteria (Professional Component) has been enhanced by being involved with the steel bridge and concrete canoe projects. The results are also compared with students who have practical civil engineering experience. In particular, the findings suggest that students who are directly involved with project work believe that four areas have been greatly enhanced. They include: structural engineering, project management/scheduling and estimating, constructability and team work. Understanding of engineering codes and standards, health and safety issues, materials engineering, and ethical considerations are also perceived to be enhanced. Furthermore, the results complement documentation from the American Institute of Steel Construction including comments from students participating in the steel bridge competition.
\end{abstract}

\section{Introduction}

The American Society of Civil Engineers (ASCE) believes that the practice of civil engineering is broad and diverse, including numerous disciplines. As a result, the breadth of the professional Component of civil engineering education is necessarily broad. This precept is recognized by the ASCE Committee on Curriculum and Accreditation and has been adhered to in the development of the criteria for accreditation.

In this regard, numerous students and practitioners believe that being involved with the American Institute of Steel Construction (AISC) steel bridge and/or ASCE concrete canoe projects complements and enhances the theoretical and design concepts developed in class. To further investigate this perception, data were obtained from a survey instrument which was distributed to graduate and undergraduate students enrolled, in part, in construction related courses taught in civil engineering degree programs at Lamar University. The projects,

Proceedings of the 2004 American Society for Engineering Education Annual Conference \& Exposition Copyright (C) 2004, American Society for Engineering Education 
themselves, were not required in any specific class or series of classes. Nevertheless, respondents were requested to indicate whether (and at what specific level) various design activities and academic subjects are perceived to have been enhanced by working on the steel bridge and concrete canoe projects.

The subjects chosen are those that have been included in the Program Criteria for Civil and Similarly Named Engineering Programs and the General Criteria (Professional Component) that has been adopted by the Accreditation Board for Engineering and Technology (ABET) and must be satisfied for a program to be accredited ${ }^{3}$. For comparative purposes, the findings of the investigation could be utilized by other institutions and departments that may wish to study their curriculum and its relationship with student projects. In this regard a comparison was also conducted utilizing data from students who have practical experience in the field of Civil Engineering.

\section{Engineering Accreditation}

Recently, there have been recommendations from educators and technical/professional societies to revise the engineering curriculum that is being required in accredited institutions $\mathrm{s}^{4,5,7,8,10}$. Partially in response to these recommendations, the Accreditation Board for Engineering and Technology (ABET) has revised the criteria for accrediting engineering programs. The new approach shifts emphasis away from "what is being taught" to "what is being learned" and is less proscriptive of required coursework ${ }^{2}$. To assist in implementing the revised criteria, numerous conferences have been held and papers published involving the topics of accreditation and the curriculum.

\section{Students Involved with Bridge and Canoe Projects}

As a segment of a continuing review of factors related to the curriculum, a survey instrument was distributed to students enrolled in required senior and typical graduate courses offered by the Civil Engineering Department of Lamar University. The study covered a two year period and the overall rate of return of usable questionnaires was 78\%. Of the usable forms returned, $41 \%$ represented responses of students involved with and working on the steel bridge and/or concrete canoe projects. Fifty-nine percent were from students not involved with the endeavor. The tabulated results of the responses form the data base for the investigation. Specifically, the questionnaire listed various ABET civil engineering program requirements and requested respondents to indicate at which level - high, average, low, or unsure/none - each is believed to be enhanced by students involved in the design and construction of the steel bridge and concrete canoe projects. The subject areas chosen, shown in Table 1, are among those included in a recently adopted set of criteria for accrediting engineering programs, Engineering Criteria $2000^{3}$, and listed in the Program Criteria for Civil and Similarly Named Engineering Programs and the General Criteria (Professional Component).

Specifically, the findings suggest that the student perceive their understanding of many of the subject areas have been enhanced at a high level. For example, Table 1 illustrates that over 55\% 
of the students involved with and working on the projects believe that five areas are enhanced at a high category level. As shown, they include:

- Materials Engineering (63.2\%)

- Structural Engineering (68.4\%)

- Project Management/Scheduling and Estimating (57.9\%)

- Team Work $(89.5 \%)$

- Manufacturability (Constructability) (68.4\%)

In addition, the following four subjects are perceived to be enhanced between $35-55 \%$ in the high level category:

- Engineering Codes and Standards (36.8\%)

- Ethical Considerations (42.1\%)

- Health and Safety Issues (47.4\%)

- Political Factors $(36.8 \%)$

The nine areas listed above are perceived by students to be enhanced at a relatively high level. They include the traditional subjects of materials and structural engineering as well as the concepts of constructability, and engineering codes and standards. These areas are strongly needed in project work. Team work, project management/scheduling and estimating, and health and safety issues are also considered very important. Students appear to recognize that consideration of these practical issues are required for a successful undertaking. Environmental and geotechnical engineering, hydraulics/hydrology/water resources, and legal issues were given a low rating in the high category. These areas were apparently not considered vital for the completion of the steel bridge and concrete canoe projects. It is perhaps significant that team work received the highest score. This reinforces Engineering Criteria 2000 which stresses the concept of team work as an attribute that should be developed in engineering students.

\section{Composite Enhancement Scores}

Table 1 illustrates that the composite scores of students directly involved with the steel bridge and concrete canoe projects. The composite enhancement score is based upon the following rating system: High $=4.0$, Average $=3.0$, Low $=2.0$, and Unsure/None $=1.0$. As show, the understanding of team work (3.7), constructability (3.6), project management/scheduling and estimating (3.6) are perceived to be enhanced at overall the highest level. Structural (3.5) and materials (3.4) engineering, codes and standards (3.2), and health and safety issues (3.3) are also enhanced. This reinforces the concept discussed in the previous section.

In addition, four subject areas were perceived to be enhanced in the low range. This is understandable since subjects such as hydraulics/hydrology/water resources (2.4), and geotechnical (2.0) and environmental (1.8) engineering were generally not taken under 
Table 1. Perceptions of Students Working on and Directly Involved with AISC/ASCE Projects

Enhanced Understanding of Theoretical and Design Class Work

Academic Areas or

$\underline{\text { Design Considerations }}$

Academic Subjects

Materials Engineering

Structural Engineering

Geotechnical Engineering

Environmental Engineering

Hydraulics/Hydrology/Water

Resources

Project Management/

Scheduling and Estimating

Design Considerations

Team Work

Engineering Codes and

Standards

Sustainability

Manufacturability

(Constructability)

Ethical Considerations

Health and Safety Issues

Social Ramifications

Political Factors

Legal Issues

\begin{tabular}{|c|c|c|c|c|}
\hline \multicolumn{4}{|c|}{ Percentage of Respondents } & $\begin{array}{c}\text { Composite } \\
\text { Score* }\end{array}$ \\
\hline$\underline{\text { High }}$ & Avg & Low & Unsure/None & \\
\hline 63.2 & 21.1 & 5.3 & 10.5 & 3.4 \\
\hline 68.4 & 21.1 & 0.0 & 10.5 & 3.5 \\
\hline 10.5 & 21.1 & 26.3 & 42.1 & 2.0 \\
\hline 0.0 & 31.5 & 21.1 & 47.4 & 1.8 \\
\hline 10.5 & 42.1 & 26.3 & 21.1 & 2.4 \\
\hline 57.9 & 42.1 & 0.0 & 0.0 & 3.6 \\
\hline 89.5 & 0.0 & 5.3 & 5.3 & 3.7 \\
\hline 36.8 & 47.4 & 15.8 & 0.0 & 3.2 \\
\hline 26.3 & 36.8 & 21.1 & 15.8 & 2.7 \\
\hline 68.4 & 26.3 & 5.3 & 0.0 & 3.6 \\
\hline 42.1 & 36.8 & 10.5 & 10.5 & 3.1 \\
\hline 47.4 & 36.8 & 15.8 & 0.0 & 3.3 \\
\hline 26.3 & 26.3 & 26.3 & 21.1 & 2.6 \\
\hline 36.8 & 15.8 & 26.3 & 21.1 & 2.7 \\
\hline 10.5 & 26.3 & 26.3 & 36.8 & 2.1 \\
\hline
\end{tabular}

* Composite Score based upon 4.0 = high; $3.0=$ average; $2.0=$ low; $1.0=$ unsure or none. 
consideration by those working on the project. This can also be said of the legal issues (2.1) involved with project work. Furthermore, the understanding of social ramifications (2.6), political factors (2.7), and sustainability (2.7) was enhanced at a slightly below average rate for those working on projects. This may be significant for educators since some of these subject areas can be difficult to take under consideration and discuss during a normal classroom setting without considerable practical examples.

\section{Project Work Compared with Practical Experience}

Table 2 illustrates that students involved with the steel bridge and concrete canoe projects perceive that their understanding of numerous subject areas (approximately one-half) have been enhanced at roughly the same score as that of students who have practical civil engineering experience. In this regard, the data for students with practical experience has been obtained from a previous paper ${ }^{6}$.

The results in Table 2 show that structural Engineering and Engineering Codes and Standards have been enhanced at the same score for both groups. Nevertheless, the composite score for Geotechnical Engineering, Environmental Engineering, and Hydraulics/Hydrology/Water Resources suggests that practical experience rather than project work may enhance understanding in these subject areas at a higher rate $(\geq 0.7)$. This difference was explained, in part, in the previous section. Social Ramifications and Legal Issues are also believed to be enhanced at a higher rate on the engineering work-site $(\geq 0.5)$.

In contrast to the above, constructability is enhanced at a higher composite score for project students compared to those with practical experience. This is to be expected since both the steel bridge and concrete must be constructed by the students involved with the projects. Overall, it appears that practical experience may enhance understanding of engineering course work at a more balanced comprehensive level compared to steel bridge and concrete canoe project work.

\section{ABET and the Student Steel Bridge Competition}

The AISC Student Steel Bridge Contest (SSBC) can be considered to be a scaled simulation of a representative engineering project. Participating students are given the opportunity to enjoy the excitement of competition while exercising many of the abilities required of a practicing engineer.

In order to assist Civil Engineering Departments, the AISC Partners in Education Committee (PIE) has documented an approach utilizing the SSBC that may help departments to comply with ABET criteria ${ }^{1}$. Specifically, documentation was developed that matches different aspects of the steel bridge competition with various ABET criteria contained in Criterion 3. The compilation, including the enhancement perceptions from the present investigation, is illustrated below. It is shown that the student perceptions from this study complement the SSBC and the various factors

\footnotetext{
Proceedings of the 2004 American Society for Engineering Education Annual Conference \& Exposition Copyright (C) 2004, American Society for Engineering Education
} 
Table 2. Perceptions of Students Working On and Involved with AISC/ASCE Projects in contrast to Students with Practical Experience

Academic Areas or Design

Considerations

Materials Engineering

Structural Engineering

Geotechnical Engineering

Environmental Engineering

Hydraulics/Hydrology/Water

Resources

Project Management/

Scheduling and Estimating

Team Work

Engineering Codes and

Standards

Sustainability (Life Cycle

Costs)

Manufacturability

(Constructability)

Ethical Considerations

Health and Safety Issues

Social Ramifications

Political Factors

Legal Issues

Enhanced Understanding of Theoretical and Design Class work

Students Involved with

Projects*

3.4

3.5

2.0

1.8

2.4

3.6

3.7

3.2

2.7

3.6

3.1

3.3

2.6

2.7

2.1
Students with Practical

Experience*

3.3

3.5

3.4

3.1

3.1

3.7

3.5

3.2

3.1

3.1

3.5

3.4

3.1

2.6

2.9

* Composite score based upon $4.0=$ high; $3.0=$ average; $2.0=$ low; $1.0=$ unsure or no 
required for accreditation. It can also be seen that the Student Steel Bridge Project may possibly assist in satisfying ABET criteria. However, participation in the SSBC must probably be required of all students in order to satisfy ABET criteria for a specific curriculum. Unfortunately, this may be difficult to accomplish in all circumstances.

\section{Student Contest Implements ABET Criteria}

\begin{tabular}{|c|c|c|}
\hline $\begin{array}{l}\text { Criterion 3, } \stackrel{\text { ABET }}{\text { Program }} \\
\text { Outcomes and Assessment: } \\
\text { "Engineering programs must } \\
\text { demonstrate that their } \\
\text { graduates have an ability to: }\end{array}$ & $\begin{array}{l}\qquad \text { AISC - SSBC } \\
\text { Rules booklet: "Civil } \\
\text { Engineering students are } \\
\text { challenged to an inter- } \\
\text { collegiate competition that } \\
\text { includes design, fabrication } \\
\text { and construction." }\end{array}$ & $\begin{array}{l}\quad \text { Student Perceptions } \\
\text { Enhancement of the subjects } \\
\text { listed in Table } 1\end{array}$ \\
\hline $\begin{array}{l}\text { a. ...apply knowledge of } \\
\text { mathematics, science and } \\
\text { engineering }\end{array}$ & $\begin{array}{l}\text { Statics, Structural Analysis, } \\
\text { Materials, Steel Design, } \\
\text { Construction Management. }\end{array}$ & $\begin{array}{l}\text { Structural Engineering } \\
\text { Materials Engineering }\end{array}$ \\
\hline $\begin{array}{l}\text { b. ...design and conduct } \\
\text { experiments } \\
\text {... analyze and interpret data }\end{array}$ & $\begin{array}{l}\text { Testing properties of different } \\
\text { grades of steel. Comparing } \\
\text { alternative designs using } \\
\text { computer models and } \\
\text { prototypes. }\end{array}$ & Materials Engineering \\
\hline $\begin{array}{l}\text { c. ...design a system, } \\
\text { component or process to meet } \\
\text { desired needs }\end{array}$ & $\begin{array}{l}\text { Designing a structure and } \\
\text { erection process to satisfy } \\
\text { requirements and optimize } \\
\text { score. }\end{array}$ & $\begin{array}{l}\text { Sustainability (Life-cycle } \\
\text { costs) }\end{array}$ \\
\hline $\begin{array}{l}\text { d. ...function on multi- } \\
\text { disciplinary teams }\end{array}$ & $\begin{array}{l}\text { Optionally working with } \\
\text { students in construction } \\
\text { management, architecture and } \\
\text { business (funding, budget, } \\
\text { purchasing). }\end{array}$ & $\begin{array}{l}\text { Team Work, Project } \\
\text { Management }\end{array}$ \\
\hline $\begin{array}{l}\text { e. ...identify, formulate and } \\
\text { solve engineering problems }\end{array}$ & $\begin{array}{l}\text { Defining and solving } \\
\text { problems inherent to design, } \\
\text { fabrication and organization. }\end{array}$ & Legal Issues, Constructability \\
\hline $\begin{array}{l}\text { f. ...understanding } \\
\text { professional and ethical } \\
\text { responsibility }\end{array}$ & $\begin{array}{l}\text { Conforming to the rules, } \\
\text { sportsmanship, teamwork. }\end{array}$ & Ethical Considerations \\
\hline
\end{tabular}

Proceedings of the 2004 American Society for Engineering Education Annual Conference \& Exposition Copyright $\mathbb{C}$ 2004, American Society for Engineering Education 


\section{g. ...communicate effectively}

i. ...recognition of need for, and ability to engage in lifelong learning

k. ...use techniques, skills and modern engineering tools..."
Typical team sizes of five to ten necessitate effective communication including clear and complete computation sheets and drawings, meeting agendas and minutes.

Designers typically explore topics beyond their classes, e.g. stability, optimization, high alloy steels. They are practicing self-study, a lifelong learning skill.

Spread sheets, structural and analysis programs, computeraided drafting, ...
Project Management, Teamwork

Social Ramifications

The AISC has distributed statements from students participating in a competition related to what they have learned from being a member of a steel bridge team ${ }^{9}$. Comments include that students perceive that not only their technical but also their leadership skills were increased and/or developed by the endeavor. In addition, the understanding of various concepts discussed in class was enhanced. These beliefs complement those of Lamar University students.

Summary and Conclusions

This paper reviews a number of recent recommendations involving engineering education. In addition, it presents the results of an investigation of the perceptions of a group of engineering students, concerning the level at which various civil engineering accreditation requirements have been enhanced by project work. Data for the study were obtained from a questionnaire which was completed by students enrolled in various civil engineering degree programs. The findings of the investigation could be utilized, for comparative purposes, by other institutions and departments that may wish to study their curriculum and how it relates to the steel bridge and concrete canoe projects. In this regard, a comparison was made to documentation from AISC including comments from students participating in a competition.

The project work itself at Lamar University was not required in a specific course or series of courses. It is questionable whether it should be recommended, in order to satisfy ABET accreditation requirements, that all students must participate in steel bridge or concrete canoe projects as part of the curriculum. One significant problem that must be considered is that some students do not wish to be involved or support this type of project work.

Proceedings of the 2004 American Society for Engineering Education Annual Conference \& Exposition Copyright (C) 2004, American Society for Engineering Education 
Nevertheless, the high percentage category and composite scores suggest that students working on projects believe that their understanding of four areas has been greatly enhanced. They include: structural engineering, project management/scheduling and estimating, team work, and manufacturability (constructability). Furthermore, it is believed that the understanding of the following subjects has been enhanced at an above average level: engineering codes and standards, health and safety issues, materials engineering, and ethical considerations. However, data suggest that, overall, it appears that practical experience may enhance understanding of civil engineering course work at a more balanced comprehensive level compared to steel bridge and concrete canoe project work.

Nevertheless, many of the aforementioned subject areas are required by ABET as criteria that must be satisfied for a program to be accredited. Specifically, they are included in Engineering Criteria 2000 which was adopted by ABET and are listed in the Program Criteria for Civil and Similarly Named Engineering Programs and the General Criteria (Professional Component) and will be required by all programs for accreditation purposes in the year 2001-2002. It appears, therefore, that the knowledge and experience gained by students working on steel bridge and concrete canoe projects may complement the criteria required for accreditation. In addition, the activities should enhance the skills required by engineering students for a successful career involving the design and management of engineering and construction projects.

\section{Bibliography}

1 Blackburn, S.H., Reaveley, L.D., et al., (2002). “ABET and Student Steel Bridge Competition.” American Institute of Steel Construction, Inc., One East Wacker Drive, Chicago, Illinois.

2 Bordogna, J. (1998). “Tomorrow's Civil Systems Engineer - The Master Integrator.” Journal of Professional Issues in Engineering Education and Practice, ASCE, 124(2), 48-50.

3 Engineering Criteria 2000 (2003). Engineering Accreditation Commission of the Accreditation Board for Engineering and Technology (ABET), Baltimore, MD, http://www.abet.org.

4 Engineering Education for a Changing World. (1994). American Society for Engineering Education (ASEE), Washington, D. C.

5 Hampton, D. (2000). "More Education is needed for Civil Engineers." ASCE News, ASCE 25(1), 6.

6 Koehn, E., (2004). "Enhancing Civil Engineering Education and ABET Criteria through Practical Experience." Accepted for publication in the journal of Professional Issues in Engineering Education and Practice.

7 Koehn, E. (1997). "Engineering Perceptions of ABET Accreditation Criteria." Journal of Professional Issues in Engineering Education and Practice, ASCE, 123(2), 66 - 70.

8 Long, R. P. (1997). "Preparing Engineers for Management." Journal of Management in Engineering, ASCE, 13(6), $50-54$.

9 Rosenberg, F. (2003). "What Students Say." American Institute of Steel Construction, Inc, One East Wacher Drive, Chicago, Illinois.

10 "What Does the Future Hold for C.E.'s? (2000). ASCE News, ASCE, 25(1), 6. 


\section{ENNO "ED" KOEHN}

Enno "Ed" Koehn is a Professor of Civil Engineering at Lamar University, Beaumont, TX. Professor Koehn has served as the principal investigator for several research and development projects dealing with various aspects of construction and has experience in the design, scheduling, and estimating of facilities. In addition, he has authored/co-authored approximately 200 papers and presentations in engineering education and the general areas of civil and construction engineering. Dr. Koehn is a member of ASEE, AACE International, ASCE, NSPE, Chi Epsilon, Tau Beta Pi, and Sigma Xi and is a registered Professional Engineer and Surveyor.

Rajesh D. Malani

Rajesh D. Malani is currently a graduate student of Civil Engineering at Lamar University, Beaumont, TX. He has served as a Technical Assistant at the reputed Indian Institute of Technology ( I.I.T) Mumbai 